\title{
İş Özerkliği ile İşe Bağlanma Arasındaki İlişki: Kişi-iş Uyumunun Aracı ve Algılanan Yönetici Desteğinin Düzenleyici Rolü
}

Daimi Koçak ${ }^{1}$

\begin{abstract}
İş Özerkliği ile İşe Bağlanma Arasındaki îlişki: Kişi-iş Uyumunun Aracı ve Algılanan Yönetici Desteğinin Düzenleyici Rolü
\end{abstract}

Öz

Bu çalışmada, iş özerkliği ve işe bağlanma arasındaki ilişkide kişi-iş uyumunun aracılık rolünü araştırdım ve algılanan yönetici desteğinin bu aracılık ilişkisinde önemli bir düzenleyici olabileceğini ileri sürdüm. Araştırma verileri hizmet sektöründe faaliyet gösteren özel iki firmanın tam zamanlı çalışan 385 işgöreninden anket tekniği kullanılarak toplanmıştır. Verilerin analiz edilmesinde SPSS 22, AMOS 22 ve Process Macro (SPSS için) istatistik programları kullanılmıştır. Analiz sonuçları, iş özerkliği ve işe bağlanma arasındaki ilişkide kişi-iş uyumunun aracı etkisinin olduğunu ve algılanan yönetici desteğinin bu ilişkide düzenleyici etkisinin olduğunu desteklemektedir. Diğer bir ifade ile iş özerkliğinin işe bağlanma üzerindeki dolaylı etkisi (kişi-iş uyumu aracılı̆̆ı ile aktarılan) algılanan yönetici desteği yüksek olduğunda güçlü, düşük olduğunda zayıftır. Araştırmanın teorik ve pratik etkileri tartışılarak gelecekte yapılacak çalışmalara ve yöneticilere önerilerde bulunulmuştur.

Anahtar Kelimeler: İş Özerkliği, Kişi-iş Uyumu, İ̧̧e Bağlanma, Algılanan Yönetici Desteği
The Relationship between Job Autonomy and Job Engagement: The Mediating Role of Person-Job Fit and Moderating Role of Perceived Supervisor Support

Abstract

In this study, I explored the mediating role of person-job fit in the relationship between job autonomy and job engagement and proposed perceived supervisor support as an important moderator of the above mediated relationship. The survey data were collected from 385 full-time employees of two private firms operating in the service sector using the survey technique. SPSS 22, AMOS 22 and Process Macro (for SPSS) statistical programs were used to analyze the data. The results of the analysis indicated that the person-job fit has a mediating effect on the relationship between job autonomy and job engagement, and perceived supervisor support has a moderating effect in this relationship. In other words, the indirect effect of job autonomy on job engagement (through person-job fit) is strong when perceived supervisor support is high and weak when perceived supervisor support is low. The theoretical and practical effects of the results are discussed and suggestions are made for future studies and managers.

Keywords: Job Autonomy, Person-Job Fit, Job Engagement, Perceived Supervisor Support

\section{Giriş}

Çalışanların yaptıkları işe bağlı olmaları işletmeler için son derece büyük bir öneme sahiptir. Araştırmacılar örgütlerin yüksek seviyede performansa ve verimliliğe sahip olmalarında işe bağlanma seviyesi yüksek çalışanların çok büyük katkılarının olduğunu savunurlar (Kahn, 1990; Maslach vd., 2001; Schaufeli vd., 2002; Saks, 2006; Bakker ve Demerouti, 2008). İşe bağlanma seviyesi yüksek çalışanların örgüte bağlılıklarının (Hallberg ve Schaufeli, 2006), performanslarının (Rich vd. 2010) ve örgütsel vatandaşlık davranışlarının (Kataria vd. 2013) yüksek, öte yandan işten ayrılma niyetlerinin ise düşük olduğu araştırmacılar tarafından ortaya konmuştur (Yalabık vd. 2013). Yapılan araştırmalara göre Amerika'da, çalışanların yarısından çoğunun işlerine bağlı olmamalarının işletmelere yıllık maliyetinin yaklaşık olarak 300 milyar Dolar olduğu hesaplanmıştır (Saks, 2006). Hooper (2006) Avustralya'da yaptığı bir araştırma sonucunda Amerika'daki bu sonucu destekleyen bulgulara ulaşmıştır. Hooper işlerine bağlanma seviyesi düşük olan çalışanların Avustralya'daki işletmelere yıllık maliyetinin 31 milyar Dolar civarında olduğunu tespit etmiştir. Peki, işletmeler çalışanların işe bağlanmalarını nasıl sağlayabilir ve artırabilirler?

\footnotetext{
${ }^{1}$ Dr. Öğr. Üyesi, Erzincan Binali Yıldırım Üniversitesi, Ali Cavit Çelebioğlu Sivil Havacılık Yüksekokulu, Havacılık Yönetimi Bölümü, dkocak@erzincan.edu.tr, Yazar ORCID bilgisi: https://orcid.org/0000-0001-9099-2055
} 
Çalışanların işe bağlanmalarını etkileyen birçok faktör vardır (örneğin; örgütsel destek, geribildirim, örgütsel adalet). Bireylerin işlerini yaparken sahip oldukları özgürlük ve bağımsızlık seviyesi ile ilgili olan iş özerkliği (Hackman ve Oldham, 1976), işe bağlanmayı etkileyen faktörlerden birisidir (Hallberg vd. 2007; Hallberg ve Schaufeli, 2006). İş özerkliğinin işe bağlanma üzerinde önemli bir belirleyici olduğunu iddia eden çalışmalar incelendiklerinde, çalışanların yaptıkları işle uyumlu olmalarının (kişi-iş uyumu) göz ardı edildiği görülmüştür (Hallberg ve Schaufeli, 2006; Saks, 2006; Hallberg vd., 2007; Bakker ve Demerouti, 2008; Lin ve Ping, 2016). Sekiguchi'ye (2004) göre kişi-iş uyumu çalışanların işe alımlarında önemli bir belirleyicidir ve çalışan seçiminde öncelikli konu, çalışanın işi yapabilecek beceri ve yeteneklere sahip olmasıdır. Kahn (1990) çalışanın işe bağlanmasına birçok faktörün etki edeceğini savunmuştur. İşe bağlanmaya etki eden faktörleri inceleyen araştırmacılar Kahn'ın bu varsayımını destekleyici sonuçlara ulaşmışlardır. İ̧̧ özerkliğinin işe bağlanma üzerindeki etkisini araştıran bazı araştırmacılar bu ilişkide başka faktörlerin etkilerinin de incelenmesi gerektiğini ileri sürmüşlerdir (Lin ve Ping, 2016; Orth ve Volmer, 2017; Malinowska vd., 2018). Araştırmacılar (Lu vd., 2014; Sulistiowati vd., 2018; Hamid ve Yahya , 2016; Memon vd., 2015) kişinin yaptığı iş ile uyumunun artması durumunda işine daha fazla bağlanacağını ortaya koymuşlardır. Ayrıca yapılan araştırmalar (Saks, 2006; Schaufeli, 2013) çalışanların algıladıkları yönetici desteğinin işe bağlanmalarını etkileyen önemli bir unsur olduğu yönündedir. Bu nedenle bu çalışmada iş özerkliğinin işe bağlanma üzerindeki etkisi incelenirken kişi-iş uyumunun ve algılanan yönetici desteğinin bu ilişkiye olan etkileri incelenmiştir.

Bu çalışmanın amacı, iş özerkliği, kişi-iş uyumu, algılanan yönetici desteği ve işe bağlanma değişkenleri arasındaki potansiyel ilişkiler analiz edilerek, iş özerkliğinin işe bağlanma üzerinde kişi-iş uyumu aracılığıyla aktarılan dolaylı bir etkinin olup olmadığı ve algılanan yönetici desteğinin seviyesine göre bu dolaylı etkinin değişip değişmediğinin tespit edilmesidir. Böylece, kişiiş uyumu ve işe bağlanmanın öncülleri ve iş özerkliği ve yönetici desteğinin sonuçları hakkında literatüre katkı yapmak amaçlanmaktadır. Ayrıca çalışma sonuçları işletme yöneticilerine kişi-iş uyumu ve işe bağlanmaya etki eden öncüller hakkında bilgi vererek çalışanların işe bağlanmalarını artırmaya yönelik daha etkili kararlar almalarına katkı yapacaktır.

\section{Teorik Çerçeve ve Araştırma Hipotezleri}

\section{1. İ̧̧ özerkliği}

İş tasarım teorileri, işlerin, rollerin ve görevlerin nasıl yapılandırıldıkları, yasallaştırıldıkları ve nasıl değiştirildikleri ve bunların birey, grup ve örgüt üzerindeki etkileri hakkında bilgi verirler (Torraco, 2005:85). illk başlarda işin sadeleştirilmesine odaklanan iş tasarım teorileri (örneğin Taylor, 1911), ilerleyen yıllarda işin motive edici özelliklerine odaklanmışlardır. Bu teoriler içerisinde Hackman ve Lawler (1971) tarafından geliştirilen İş Karakteristikleri Modeli, çalışan-örgüt ilişkilerinin daha iyi anlaşılmasına önemli katkı yapmıştır (Dysvik ve Kuvaas, 2013:564). Araştırmacılar (Hackman ve Lawler, 1971; Hackman ve Oldham, 1976) işin bu karakteristiklerinden birisinin işin özerkliği olduğunu savunmuşlardır (diğerleri beceri çeşitliliği, görev kimliği, görev anlamlılığı ve geribildirim). İşin özerkliği, "işin planlanmasında, yürütülmesinde ve kullanılacak prosedürlerin belirlenmesinde, bireye özgürlük, bağımsızlık ve takdir yetkisi sağlama derecesidir" (Hackman ve Oldham, 1976). Çalışana çok fazla özerklik verilen bir işte, sonuçlar ne yöneticinin talimatlarına nede iş prosedürlerine bağlıdır. Sonuçlar daha çok çalışanın kendi çabasına, kararlarına ve inisiyatif almasına bağlıdır. Özerkliğin artması, bireylerin işin nasıl yapılacağı konusunda takdir yetkilerini artıracağından, rollerini tanımlarken daha fazla esnek olmalarına katkıda bulunacaktır (Morgeson vd., 2005). İş özerkliği ile ilgili yapılan çalışmalar, iş özerkliğinin 
artması durumunda öz-yeterlilik (Saragih, 2011), iş memnuniyeti (Nguyen vd., 2003), örgütsel bağlılık (Naqvi vd., 2013; Sisodia ve Das, 2013), algılanan örgütsel destek (Alvi vd., 2013), yaratıcılık (Sia ve Appu, 2015), dirilik (canlılık) (Tummers vd., 2018), bilişsel yetenek, performans (Morgeson vd., 2005) ve işe bağlanma (Lin ve Ping, 2016; Orth ve Volmer, 2017; Malinowska vd., 2018) gibi örgütsel amaç ve hedeflerin gerçekleştirilmesine olumlu katkı yapan unsurların arttığını, öte yandan işe yabancılaşma (Özkoç, 2016), tükenmişlik (Adebayo ve Ezeanya, 2011) ve işten ayrılma niyeti (Galletta vd., 2011) gibi olumsuz unsurların ise azaldığını ortaya koymuşlardır.

\section{2. İş Özerkliğinin Kişi-Iş Uyumu Üzerindeki Etkisi}

İ̧̧ karakteristikleri teorisi, bireyin içsel motivasyonunun artması için yaptığı işin sonuçları ile ilgili sorumluluk hissetmesi gerektiğini savunur (Hackman ve Oldham, 1976). Çalışanların yaptıkları işteki algıladıkları özerkliğin artması, işin anlamlılığını artırarak (Lin ve Ping, 2016) işleriyle olan uyumlarının artmasına katkı yapar (Scroggins, 2008). Sekiguchi (2011) işletme yöneticilerinin kişi-iş uyumunu iş karakteristiklerini dikkate alarak sağlayabileceklerini savunmuştur. Kişi-iş uyumu Dawis vd. (1964) tarafından geliştirilen ve işe uyum teorisine dayanan bir kavramdır. Bu teoriye göre, bireyin yetenekleri ile işin gerektirdiği roller ne kadar uyumluysa, bireyin işi daha iyi yapma olasılığı o kadar yüksek olur. Kişi-iş uyumu, kişinin özellikleri (bilgi, beceri, yetenek ve intiyaçlar) ile işin gerekliliklerinin uyumu veya kişinin intiyaçları/arzuları ile işin özelliklerinin uyumlu olması olarak tanımlanabilir (Edwards, 1991). Kişi-iş uyumu arz-ihtiyaç uyumu ve talepyetenek uyumu şeklinde iki unsurdan oluşmaktadır. Arz-ihtiyaç uyumu bir işin niteliklerinin (örneğin, özerkliği) çalışanların kişisel isteklerini, değerlerini ve ihtiyaçlarını karşılayıp karşılamadığını ölçmek için kullanılır (Carless, 2005). Öte yandan, talep-yetenek uyumu ise bir kişinin bilgi, beceri ve yeteneklerinin işin talep ve gereklilikleri ile uyuşma derecesini ifade eder (Sekiguchi, 2004). Kerse (2018) yaptığı araştırma sonucunda iş becerikliliği artan çalışanların işleriyle uyumlarının da arttığını tespit etmiştir. Karasek (1979) tarafından ortaya konan Iş Talep-Kontrol (ITK) modeline göre, çalışanların yaptıkları iş üzerindeki kontrolleri (karar verme özerkliği) düşük ve kendilerinden beklenen iş miktarı yüksek olursa bu durum çalışanlar üzerinde psikolojik baskıya yol açar. Örneğin, Rafferty vd. (2001) iTK modeline göre yaptıkları çalışma sonucunda yüksek iş talepleri ve düşük iş özerkliğinin çalışanların tükenmişliklerini artırdığını, öte yandan Babakuş vd. (2011) tarafından yapılan çalışmada ise tükenmişliği artan çalışanların işleriyle uyumlarının azaldığı tespit edilmiştir.

Yukarıda yapılan açıklamalar doğrultusunda aşağıdaki hipotez geliştirilmiştir:

Hipotez 1. İş özerkliği kişi-iş uyumu ile pozitif ilişkilidir.

\section{3. İş Özerkliği ve İşe Bağlanma İlişkisinde Kişi-iş Uyumunun Aracı Etkisi}

İşe bağlanma kavramı, özellikle son yıllarda, gerek işletmelerde gerekse akademik çalışmalarda dikkate alınan bir kavram haline gelmiştir (Saks, 2006:601). Illk kez Kahn (1990) tarafından ortaya konan işe bağlanma kavramı Goffman'ın (1961) rol teorisine dayanılarak tanımlanmıştır. İşe bağlanma kavramı bireylerin deneyimlerine, işlerine ve iş ortamlarına odaklanan psikolojik koşullar teorisiyle ilişkili olan bir kavramdır. Kahn (1990) işe bağlanmayı; bireyin bilişsel, duyuşsal ve davranışsal olarak kendisini yaptığı işe vermesi, yaptığı işin rollerine kedisini adaması olarak tanımlamıştır. İşe bağlanmanın bilişsel yönü çalışanların organizasyon, lider ve çalışma koşulları hakkındaki inançlarıyla; duygusal yönü çalışanların kuruluş ve liderlerine karşı hissettikleri olumlu ya da olumsuz tutumlarıyla; ve fiziksel yönü ise, bireylerin rollerini yerine getirmek 
için harcadıkları fiziksel enerjileriyle ilgilidir (Kular vd., 2008). İşe bağlanma kavramı, sonraki yıllarda farklı araştırmacılar tarafından farklı açılardan incelenerek ele alınmıştır. Örneğin; Maslach vd., (2001) bağlanma kavramını, tükenmişliği ifade eden bitkinlik, sinizm ve kişisel başarıda düşme hissinin karşıtı olan enerji, katılım ve yeterlilik olarak; Hallberg ve Schaufeli, (2006:119) kişinin bir işi severek, Israrla ve olumlu duygusal motivasyonla yerine getirmesi olarak; Leiter ve Bakker (2010) tükenmişliğin tersi olarak; ve Schaufeli vd. (2002) ise dinçlik (vigor), adanma (dedication) ve yoğunlaşma (absorption) boyutlarından oluşan olumlu bir durum olarak tanımlamıştır. Kahn'a (1990) göre bireyin işe bağlanması, işin psikolojik anlamlılığına ilişkin sorulara vereceği yanıtlara göre şekillenir. Psikolojik anlamlılık bireyin işin gerektirdiği rol performansına yaptığı fiziksel, bilişsel ve duygusal katkının karşılığını alması duygusunu ifade eder (Kahn, 1990:703). Saks'a (2006:602) göre işin gerektirdiği görevin özellikleri bir işin psikolojik anlamlıığını etkileyen önemli bir faktördür. Bireylerin yaptıkları işi anlamlı bulmaları, işin gerektirdiği görevlerin yaratıcılığa açık olması, açıkça tanımlanmış olması ve özerkliğe açık olması gerekir (Jacobs, 2013:57).

İşe bağlanma kavramını ortaya çıkaran çalışmalar incelendiğinde birçoğunun iş özerkliğinin önemini vurguladıkları görülmüştür (örneğin; Kahn, 1990; Demerouti vd., 2001; Saks, 2006; Bakker ve Demerouti, 2008; Christian vd. 2011). İş özerkliği ve işe bağlanma arasındaki ilişkiyi araştıran çalışmalar, bu iki kavram arasında pozitif yönlü bir ilişki olduğunu tespit etmişlerdir (Hallberg ve Schaufeli, 2006; Saks, 2006; Hallberg vd., 2007; SheeMun vd., 2013; Lin ve Ping, 2016; Vera vd., 2016; Orth ve Volmer, 2017; Malinowska vd., 2018; Tummers vd., 2018). Araştırmacılar iş özerkliğinin işe bağlanma üzerindeki etkisinin tek başına incelenmesinin yeterli olmayacağını savunurlar (Kahn, 1990; Lin ve Ping, 2016; Orth ve Volmer, 2017; Malinowska vd., 2018). Demerouti vd. (2001) tarafından geliştirilen iş talep- kaynak modeline göre, çalışanların işe bağlanmaları artan iş taleplerinden (örneğin, vardiyalı çalışma, aşırı iş yükü, zaman baskısı) ve azalan iş kaynaklarından (örneğin, özerklik, katılım, geribildirim) negatif olarak etkilenir. Bu çalışma iş özerkliğinin işe bağlanma üzerindeki etkisinde kişi-iş uyumunun önemli bir değişken olduğunu öne sürmektedir. Kişi-iş uyumunun yüksek seviyede olması iş tatmini (O'Reilly vd., 1991; Iqbal vd., 2012; Guan vd., 2010), performans (O'Reilly vd., 1991; June ve Mahmood, 2011), örgütsel bağlılık (Leng ve Chin, 2016; Chhabra, 2015), işte kalma niyeti (Leng ve Chin, 2016) gibi çıktıları olumlu yönde etkiler. Ayrıca kişi-iş uyumu ile işe bağlanma ilişkisine yönelik yapılan araştırmalar (Lu vd., 2014; Sulistiowati vd., 2018; Rahmadani ve Sebayang, 2017; Hamid ve Yahya, 2016; Memon vd., 2015; Warr ve İnceoğlu, 2012) bireylerin işleri ile uyum seviyeleri arttıkça işe bağlanma seviyelerinin de arttığı yönünde sonuçlar ortaya çıkarmışlardır.

Bu açıklamalar doğrultusunda aşağıdaki hipotez ortaya konmuştur:

Hipotez 2. Kişi-iş uyumunun iş özerkliği ve işe bağlanma arasındaki ilişkide aracı etkisi vardır.

\subsection{Algılanan Yönetici Desteğinin Düzenleyici Etkisi}

İşe bağlanma ile ilgili yapılan araştırmalar, çalışanların işlerine bağlanmalarına etki eden birçok faktörün olduğu yönündedir. Kişi-iş uyumu bu faktörlerden birisidir (Lu vd., 2014; Sulistiowati vd., 2018; Rahmadani ve Sebayang , 2017). Bu çalışmada çalışanların işleriyle olan uyumlarının işlerine bağlanmaları üzerindeki etkisinde yönetici desteğinin önemi araştırılmıştır.

Eisenberger vd. (2002) algılanan yönetici desteğini (AYD), çalışanların örgüte yaptıkları katkıların yöneticiler tarafından ne kadar değerli görüldüğü ve bu katkı sonucunda refahlarının (iyi oluşlarının) ne kadar önemsendiği yönünde sahip oldukları algı olarak ifade etmiştir. Çalışanlar 
yönetici desteğini farklı şekillerde algılayabilirler. Örneğin yöneticinin kendilerine uygun görevler vermesi, geribildirimde bulunması, yaptıkları işte özerklik vermesi çalışanların yönetici desteği algılarının artmasını sağlar (Maertz vd., 2007). Kahn'a (1990) göre çalışanın bir işi yaparken özerk olması işine bağlanmasına etki eden önemli bir durumdur. Bu durum karşılıklılık normu (Gouldner, 1960) açısından ele alındığında, yöneticilerin kendilerine yüksek seviyede destek sağladığını algılayan çalışanlar, bunun karşııı̆ında örgüte katkı yapmak konusunda kendilerini zorunlu hissettikleri söylenebilir (Diekmann, 2004). Örneğin, yapılan çalışmalar yönetici desteği algısı yüksek olan çalışanların düşük olanlara göre gönüllü olarak örgütten ayrılma olasılıklarının daha düşük (Eisenberger vd., 2002), örgüte bağlııklarının (DeConinck ve Johnson, 2009; Kalidass ve Bahron, 2015) ve örgütsel vatandaşlık davranışlarının daha yüksek (Wang, 2014) olduğunu bulmuşlardır. Saks'a (2006) göre çalışanların işlerine bağlanmaları yönetici desteğinin bir karşılığıdır. Diğer bir ifade ile çalışanlar, algıladıkları yönetici desteği arttıkça işlerini daha iyi yapmalarına olumlu etkisi olan işe bağlanma seviyelerini artırarak karşılık verirler (Schaufeli, 2013).

Algılanan yönetici desteği kişi-iş uyumu ile işe bağlanma ilişkisinde iyi bir düzenleyici olabilir. Çünkü yöneticileri tarafından desteklendiklerini algılayan çalışanlar işleriyle daha uyumlu olacaklar ve sonucunda işlerine daha fazla bağlanacaklardır (ibrahim vd., 2019). Çalışanların yaptıkları işle uyumlarının işe bağlanmalarını nasıl etkileyeceği yöneticilerinin kendilerine vereceği desteğe bağlıdır. Diğer bir ifade ile çalışanların algıladıkları yönetici desteği arttıkça yaptıkları işle uyumlarının işe bağlanmaları üzerindeki etkisi güçlenecek, azaldıkça ise zayıflayacaktır. Nitekim algılanan yönetici desteği ile işe bağlanma arasındaki ilişkiyi araştıran çalışmalar bu iki kavram arasında pozitif ve anlamlı bir ilişki olduğu yönündedir (ibrahim vd., 2019; Idris ve Dolard, 2011; Ling Suan, ve Nasurdin, 2016). Öte yandan Saks (2006) yaptığı araştırma sonucunda algılanan yönetici desteği ile işe bağlanma arasında istatistiksel olarak anlamlı bir ilişki olmadığını tespit etmiştir. Bu sonuca göre, algılanan yönetici desteği ile işe bağlanma arasındaki ilişkinin her meslekte veya sektörde aynı olmadığı söylenebilir (ibrahim vd., 2019). Ayrıca yapılan araştırmalar sonucunda algılanan yönetici desteğinin birçok çalışmada düzenleyici değişken olarak kullanıldığı görülmüştür (Ballantine ve Nunns, 1998; Kim vd., 2017; Stephens, 2016; Yongxing vd., 2017; Pramudita ve Sukoco, 2018).

Bu açıklamalar doğrultusunda, çalışanların işe bağlanmalarının yaptıkları iş üzerindeki özerkliklerine, işle uyumlu olmalarına ve algıladıkları yönetici desteği seviyesine göre değiştiği söylenebilir. Gillet vd. (2013) yaptıkları araştırma sonucunda çalışanların algıladıkları yönetici özerklik desteğinin iş memnuniyetlerini olumlu etkilediğini tespit etmişlerdir. Vera vd. (2016) iş özerkliğinin işe bağlanma üzerindeki etkisinde yöneticilerin sosyal desteklerinin düzenleyici etkisinin olduğunu ortaya koymuşlardır. Yöneticilerinin yüksek seviyede desteğini algılayan çalışanların, iş özerklikleri ve işleriyle uyumlu olmaları, dolayısıyla işlerine daha fazla bağlanmaları daha güçlü bir olasılıktır. Diğer bir ifade ile iş özerkliği ile işe bağlanma arasındaki ilişkide kişi-iş uyumunun dolaylı etkisi algılanan yönetici desteği yüksek olduğunda güçlü, düşük olduğunda ise zayıftır. Bu durum araştırmacılar (Muller vd., 2005; Edwards ve Lambert, 2007; Preacher vd., 2007) tarafından şartlı dolaylı etki olarak kavramsallaştırılmıştır.

Bu açıklamalar ve daha önce yapılmış araştırma sonuçlarına dayanarak aşağıdaki hipotezler oluşturulmuştur.

H3. Kişi-iş uyumu ile işe bağlanma arasındaki pozitif iliş̧ide algılanan yönetici desteğinin düzenleyici etkisi vardır. Diğer bir ifade ile kişi-iş uyumu ile işe bağlanma arasındaki pozitif ilişki algılanan yönetici desteği arttığında güçlü, azaldığında ise zayıftır. 
H4. İş özerkliğinin kişi-iş uyumu aracılığıyla işe bağlanma üzerindeki pozitif ve dolaylı etkisi algılanan yönetici desteği yüksek olduğunda güçlü, düşük olduğunda ise zayıftır.

Yapılan araştırmalar sonucunda ortaya çıkan hipotezler doğrultusunda araştırma modeli Şekil 1'deki gibi oluşturulmuştur. Model, iş özerkliğinin kişi-iş uyumu aracılığıyla işe bağlanma üzerindeki dolaylı etkisinin algılanan yönetici desteği seviyesine bağlı olduğunu ifade etmektedir.

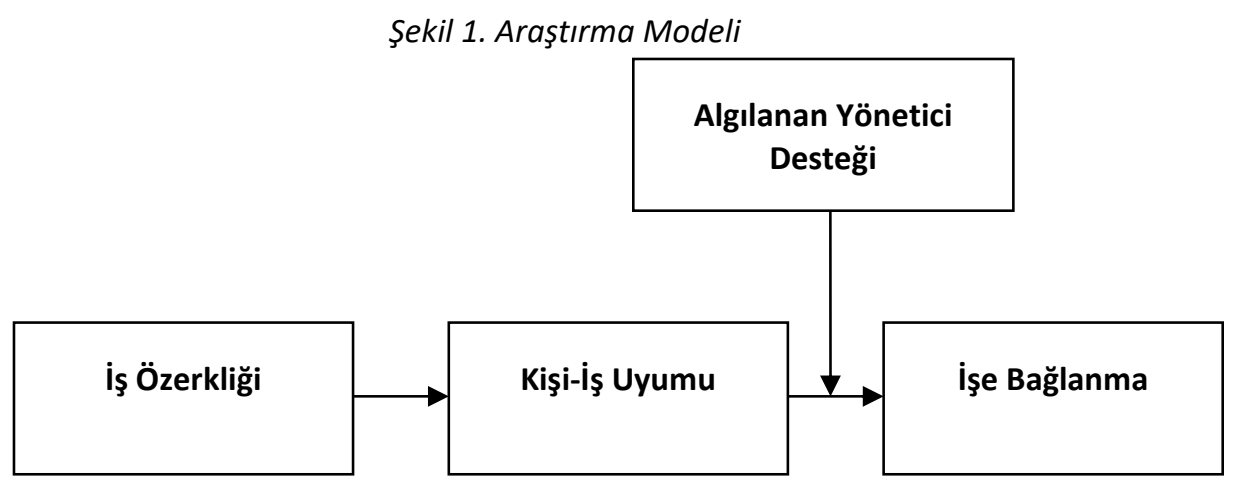

\section{Araştırmanın Yöntemi}

\section{1. Örneklem}

Araştırma evreni, Türkiye'de hizmet sektöründe faaliyet gösteren özel iki firmanın tam zamanlı çalışan 600 işgöreninden oluşmaktadır. Anketler araştırmacı tarafından çoğaltılarak posta yolu ile katılımcılara iletilmiştir. Toplamda 600 adet yollanan anketlerin 407'si (\%68) geri dönmüştür. Bu geri dönüş oranının yeterli seviyede olduğu söylenebilir (Babbie, 2001). Yapılan inceleme sonucunda 407 anketten 22 adedi sağlıklı doldurulmadığı için analizlere dahil edilmemiştir.

Yapılan inceleme sonucunda katılımcıların büyük çoğunluğunun; cinsiyetlerine göre kadın $(\% 53,9)$, yaşlarına göre $26-31$ yaş aralığında $(\% 45,7)$, medeni hallerine göre bekar $(\% 58,9)$ ve eğitim durumlarına göre önlisans mezunu oldukları $(\% 43,2)$ tespit edilmiştir.

\section{2. Ölçekler}

\subsection{1. İş Özerkliği Ölçeği}

Çalışanların yaptıkları işteki özerklik seviyelerini ölçmek için Hackman ve Oldham (1980) tarafından geliştirilen 3 maddeli "Iş Özerkliği Ölçeği” kullanılmıştır ( $\alpha=0.97)$. Ölçekteki maddeler 5’li Likert tipi ölçeğe göre derecelendirilmiştir (1-kesinlikle katılmıyorum ve 5-kesinlikle katılıyorum). Ölçekte "işimi nasıl yapacağıma karar verirken yeterli özerkliğe sahibim" şeklinde ifadeler bulunmaktadır.

\subsubsection{Kişi-iş Uyumu Ölçeği}

Araştırmada çalışanların yaptıkları işle uyumlarını tespit etmeye yönelik olarak Brkich vd. (2002) tarafından geliştirilen 9 maddeli "Kişi-iş Uyumu Ölçeği” kullanılmıştır ( $\alpha=0.88$ ). Ölçek "sahip olduğum bilgi, beceri ve yetenekler yaptığım işe uygundur" gibi ifadelerden oluşmaktadır. Katılımcılardan ölçekteki maddelere 5'li Likert tipi ölçeğe göre (1-kesinlikle katılmıyorum ve 5kesinlikle katılıyorum) yanıt vermeleri istenmiştir. 


\subsubsection{Algılanan Yönetici Desteği Ölçeği}

Çalışanların algıladıkları yönetici desteğini ölçmek için Rhoades vd. (2001) tarafından geliştirilen ve Saks (2006) tarafından adapte edilen 4 maddeli ölçek kullanılmıştır ( $\alpha=0.92$ ). Ölçekteki maddelere örnek olarak "yöneticim fikirlerimi önemser" verilebilir. Her bir ölçek maddesi 5'li Likert tipi ölçeğe göre (1-kesinlikle katılmıyorum ve 5-kesinlikle katılıyorum) derecelendirilmiştir.

\subsection{4. İşe Bağlanma Ölçeği}

Çalışanların işe bağlanma seviyelerini ölçmeye yönelik olarak $(\alpha=0.86)$ Schaufeli vd. (2006) tarafından geliştirilen 9 maddeli "İşe Bağlanma Ölçeği” kullanılmıştır. Ölçekte "sabah uyandığımda işe gitme isteği duyarım" şeklinde ifadeler bulunmaktadır. Ölçekteki ifadelere katılım derecesi 5'li Likert tipi ölçeğe göre (1-kesinlikle katılmıyorum ve 5-kesinlikle katılıyorum) derecelendirilmiştir.

\subsubsection{Kontrol Değişkenleri}

Yapılan araştırmalar, çalışanların işe bağlanmalarının eğitim seviyelerine (Kerse ve Karabey, 2019), yaşlarına (Van Wijhe vd., 2011) medeni hallerine ve cinsiyetlerine (Sia vd., 2015) göre farklılık gösterdiğini ortaya koymuştur. Bu nedenle araştırmada kontrol değişkenleri olarak katılımcılara ilişkin eğitim seviyesi, yaş, medeni hal ve cinsiyet durumu dikkate alınmıştır.

\section{Araştırmanın Bulguları ve Sonuçları}

\subsection{Betimleyici İstatistikler}

Araştırma değişkenlerine ilişkin betimleyici istatistik sonuçları (ortalamalar, standart sapmalar ve değişkenler arası ilişkiler) Tablo 1'de özetlenmiştir.

Tablo 1. Ölçeklere Ait Betimleyici Istatistik Sonuçları

\begin{tabular}{lllllll}
\hline Ölçekler & $\mathrm{M}$ & $\mathrm{SD}$ & 1 & 2 & 3 & 4 \\
\hline İ̧̧ özerkliği & 2,88 &, 94 & $(, 97)$ & & & \\
Kişi-iş uyumu & 3,04 &, 97 &, $43^{* *}$ & $(, 88)$ & & \\
Algılanan yönetici desteği & 2,91 &, 98 &, $87^{* *}$ &, $63^{* *}$ & $(, 92)$ & \\
İşe bağlanma & 3,49 &, 86 &, $54^{* *}$ &, $72^{* *}$ &, $76^{* *}$ & $(, 86)$ \\
\hline
\end{tabular}

$\mathrm{N}=385$, Değişkenlerin içsel tutarlılıkları hakkında bilgi veren Cronbach alpha değerleri parantez içerisinde verilmiştir.

Ölçekler arası korelasyon değerleri beklenildiği yönde ilişkili ve $p<0.01$ seviyesinde anlamlı çıkmıştır. Bivariate korelasyon analizi sonuçlarına göre iş özerkliği; kişi-iş uyumu ( $r=0.429$; $p<.01)$, algılanan yönetici desteği $(r=0.869 ; p<.01)$ ve işe bağlanma $(r=0.538 ; p<.01)$ ile pozitif ilişkilidir. Öte yandan kişi-iş uyumu; algılanan yönetici desteği $(r=0.625 ; p<.01)$ ve işe bağlanma ile $(r=0.716 ; p<.01)$, pozitif ilişkilidir. Son olarak algılanan yönetici desteği işe bağlanma ( $r=$ $0.763 ; p<.01)$ ile pozitif ilişkilidir.

\section{2.Ölçüm Modelleri}

Araştırmada ölçüm hatalarından biri olan ortak yöntem sapması olasılığı incelenmiştir. Ortak yöntem sapması araştırmada kullanılan veri toplama metodunun, araştırma sonucuna (bağımlı ve bağımsız değişken arasındaki ilişkinin daha yüksek veya daha düşük çıkmasına) etki etmesini ifade eder (Podsakof vd., 2003:879). Araştırma verilerinin aynı kaynakla, benzer ölçekle (örneğin 5'li Likert), farklı değişkenlere ilişkin maddelerin aynı kişi tarafından, aynı zamanda elde edilmesi durumunda ortak yöntem varyansı ortaya çıkabilir (Podsakoff vd., 2012). Ortak yöntem varyansının etkisini kontrol etmek için, veri seti üzerinde bir dizi doğrulayıcı faktör analizi (DFA) yapılmıştır. Araştırmada bütün faktörlerin ayrı olduğu 4 faktörlü model (araştırma modeli), iş özerkliği ve kişi-iş uyumunun tek faktörde birleştirildiği model (Model 1), iş özerkliği ve yönetici 
desteğinin tek faktörde birleştirildiği model (Model 2), kişi-iş uyumunun yönetici desteği ile tek faktörde birleştirildiği model (Model 3), iş özerkliği, kişi-iş uyumu ve yönetici desteğinin tek faktörde birleştirildiği model (Model 4) ve bütün değişkenlerin tek faktörde birleştirildiği model (Model 5) Tablo 2'de verilmiştir.

Tablo 2. Ölçüm Modeli ve Alternatif Modellere Illişkin Uyum Iyiliği Değerleri

\begin{tabular}{lllllll}
\hline Modeller & X2/df & RMSEA & CFI & GFI & NNFI & SRMR \\
\hline Ölçüm modeli, 4 factor & 1.664 & 0.049 & 0.968 & 0.906 & 0.911 & 0.075 \\
Model 1, 3 factor & 1.921 & 0.057 & 0.940 & 0.878 & 0.885 & 0.079 \\
Model 2, 3 factor & 2.091 & 0.063 & 0.929 & 0.864 & 0.874 & 0.092 \\
Model 3, 3 factor & 2.014 & 0.060 & 0.934 & 0.873 & 0.879 & 0.082 \\
Model 4, 2 factor & 2.319 & 0.069 & 0.914 & 0.852 & 0.860 & 0.086 \\
Model 5, 1 factor & 2.425 & 0.071 & 0.907 & 0.845 & 0.853 & 0.086 \\
\hline
\end{tabular}

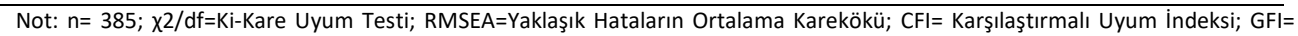
Uyum İyiliği İndeksi; NNFI=Normlaştırılmamış Uyum İndeksi; SRMR=Standartlaştırılmış Ortalama Hataların Karekökü

Üç faktörlü model (Model 1)= iş özerkliği ve kişi-iş uyumu tek faktörde birleştirildi

Üç faktörlü model (Model 2)= iş özerkliği ve yönetici desteği tek faktörde birleştirildi

Üç faktörlü model (Model 3)= Kişi-iş uyumu yönetici desteği tek faktörde birleştirildi

íki faktörlü model (Model 4)= iş̧özerkliği, kişi-iş uyumu ve yönetici desteği tek faktörde birleştirildi

Tek faktörlü model (Model 5)= Bütün değişkenler tek faktörde birleştirildi

Tablodaki değerler ölçüm modelinin $(\chi 2(249)=414.306 ; \mathrm{RMSEA}=0.049 ; \quad \mathrm{CFI}=0.968 ;$ $\mathrm{GFI}=0.906 ; \mathrm{NNFI}=0.911 ; \mathrm{SRMR}=0.075$ ) diğer modellere göre daha iyi uyum iyiliği değerlerine sahip olduğunu göstermektedir.

Ortak yöntem varyansının olup olmadı̆̆ının test edilmesinde araştırmacılar tarafından kullanılan en yaygın yöntemlerden birisi Harman'ın tek faktör testidir (Spector, 2006). Bu teknikte ortak yöntem sapmasının olduğunu söylemek için iki temel varsayım vardır; (a) faktör analizi sonucunda tek faktörlü bir yapının ortaya çıkması veya (b) ölçeklerden birisinin, kovaryansın büyük bir kısmını tek başına açıklaması gerekir. Araştırmada kullanılan dört ölçeğe ilişkin maddelerin tamamı faktör analizine tabi tutulmuştur. Yapılan analiz sonucunda özdeğeri 1'den büyük dört boyut ortaya çıkmıştır. Bu boyutlardan birincisi ölçeğe ilişkin varyansın \%33'ünü, ikincisi \%10'unu, üçüncüsü \%8'ini ve dördüncüsü \%7'sini açıklamaktadır. Bu sonuçlara dayanarak araştırmada ortak yöntem varyansı sorunun olmadığı söylenebilir (Podsakof vd., 2003).

\subsection{Hipotezlerin Test Edilmesi}

Araştırmada Hipotez 1, 2 ve 3'ün test edilmesinde hiyerarşik regresyon analizi (Wampqld ve Freund, 1987), Hipotez 4'ün test edilmesinde ise Preacher ve Hayes (2004) tarafından geliştirilen SPSS macro programı kullanılmıştır. İ̧̧ özerkliğinin işe bağlanma üzerindeki (kişi-iş uyumu aracılığı ile aktarılan) dolaylı etkisinin anlamlılı̆ını test etmek için Bootstrap metodu kullanılmıştır (Preacher ve Hayes, 2004; Preacher vd., 2007). Bu metot kullanılırken örneklem sayısı 5000 ve yanlılıktan arındırılmış güven aralığı \% 95 olarak seçilmiştir.

\subsection{Aracı Etki Analizi}

Araştırmada Hipotez 1, 2 ve 3'ü test etmek için hiyerarşik çoklu regresyon analizi kullanılmıştır. Yapılan analiz sonuçları Tablo 3'te verilmiştir. 
Tablo 3. Aracı Etkiye IIlişkin Regresyon Analizi Sonuçları

\begin{tabular}{|c|c|c|c|c|c|c|}
\hline \multirow{2}{*}{$\begin{array}{l}\text { Değişken- } \\
\text { ler }\end{array}$} & \multicolumn{4}{|c|}{ Bağımlı Değişken=işe Bağlanma } & \multicolumn{2}{|c|}{$\begin{array}{c}\text { Bağımlı Değişken =Kişi-İş } \\
\text { Uyumu }\end{array}$} \\
\hline & $\begin{array}{c}\text { Adım } 1 \\
B(p)\end{array}$ & $\begin{array}{c}\text { Adım } 2 \\
B(p)\end{array}$ & $\begin{array}{c}\text { Adım } 3 \\
B(p)\end{array}$ & $\begin{array}{c}\text { Adım } 4 \\
B(p)\end{array}$ & $\begin{array}{c}\text { Adım } 1 \\
B(p)\end{array}$ & $\begin{array}{c}\text { Adım } 2 \\
B(p)\end{array}$ \\
\hline Cinsiyet & $-.112(.072)$ & $-.077(.144)$ & $-.056(.206)$ & $-.047(.256)$ & $-.080(.201)$ & $-.052(.359)$ \\
\hline Yaş & $.020(.768)$ & $-.008(.891)$ & $.013(.784)$ & $-.001(.991)$ & $.010(.886)$ & $-.012(.840)$ \\
\hline $\begin{array}{l}\text { Medeni } \\
\text { Hal }\end{array}$ & $-.043(.504)$ & $-.044(.421)$ & $-.040(.379)$ & $-.041(.334)$ & $-.005(.944)$ & $-.005(.929)$ \\
\hline Eğitim & $-.090(.134)$ & $-.069(.176)$ & $-.053(.206)$ & $-.048(.219)$ & $-.051(.393)$ & $-.035(.527)$ \\
\hline İş Özerkliği & --------- & $.531(.000)$ & -------- & $.281(.000)$ & -------- & $.425(.000)$ \\
\hline Kiu & -------- & ------- & $.708(.000)$ & $.589(.000)$ & -------- & ------- \\
\hline $\mathbf{F}$ & 1.560 & 23.650 & 59.183 & 63.679 & .661 & 12.699 \\
\hline $\mathbf{R}^{2}$ & .022 & .301 & .519 & .583 & .010 & .188 \\
\hline
\end{tabular}

Tablodaki sonuçların yorumlanmasına geçmeden önce aracılık etkisinin varlığıyla ilgili olarak Baron ve Kenny (1986) tarafından ortaya konan bazı şartlardan bahsetmek gerekir. Bu şartlardan birincisi bağımsız değişkenin (iş özerkliğinin) bağımlı değişken (işe bağlanma) üzerindeki etkisinin anlamlı olması gerektiği yönündedir. İkinci şart bağımsız değişkenin aracı değişken (kişi-iş uyumu) üzerindeki etkisinin anlamlı olması gerektiğine vurgu yapar. Üçüncü şarta göre aracı değişken ile bağımlı değişken arasındaki ilişkinin anlamlı olması gerekir. Dördüncü ve son şarta göre ise bağısız ve bağımlı değişken arasındaki ilişki aracı değişken modele dâhil edildikten sonra anlamsızlaşıyor ise tam aracı, ilişki anlamlı fakat ilişkinin şiddetinde azalma oluyor ise kısmi aracı etki vardır. Bu açıklamalardan sonra birinci sütunun ikinci adımındaki sonuçlar ( $\beta=$ $.531 ; p<.01$ ) incelendiğinde iş özerkliğinin işe bağlanmayı pozitif ve anlamlı olarak etkilediği görülmektedir (birinci şart sağlanmıştır). Araştırmada ikinci sütunun ikinci adımında iş özerkliğinin kişi-iş uyumunu pozitif yordadığına yönelik olan birinci hipoteze ilişkin sonuçlar ( $\beta=.425 ; p<.01)$ bu hipotezi $(\mathrm{H} 1)$ desteklemektedir (ikinci şart sağlanmıştır). Birinci sütunun üçüncü adımındaki sonuçlar $(\beta=.708 ; p<.01)$ kişi-iş uyumunun işe bağlanmayı pozitif ve anlamlı yordadığını ortaya koymaktadır (üçüncü şart sağlanmıştır). Son olarak işe bağlanmanın bağımlı değişken olduğu birinci sütundaki dördüncü adımda iş özerkliği ve kişi-iş uyumu birlikte modele dâhil edilmiştir. İş özerkliğinin işe bağlanma üzerindeki doğrudan etkisinin anlamlı olduğu $(\beta=.281 ; p<.01)$ ve etkinin bir kısmının kişi-iş uyumu vasıtasıyla dolaylı olarak sağlandığı görülmektedir ( $\beta=.589$; $\mathrm{p}<.01)$. Bu sonuçlar doğrultusunda kişi-iş uyumunun iş özerkliği ile işe bağlanma arasındaki ilişkide kısmi aracı etkisinin olduğu söylenebilir. Bu sonucun tam olarak desteklenebilmesi için aracı etkinin anlamlılığının araştırılması gerekir. Araştırmacılar (Baron ve Kenny, 1986; MacKinnon vd., 2002; Preacher ve Hayes, 2004; Zhao vd., 2010) aracı etkinin anlamlı olup olmadığının test edilmesinde kullanılan en iyi yöntemlerden birisinin Sobel (1982) testi olduğunu savunmuşlardır. Yapılan Sobel testi sonucunda aracı etkinin anlamlı olduğu sonucuna ulaşılmıştır ( $z=6.72$; p<.01). Böylece Hipotez 2'nin kabul edildiği söylenebilir.

Araştırmanın diğer bir hipotezi kişi-iş uyumu ile işe bağlanma arasındaki ilişkinin algılanan yönetici desteğinin seviyesine göre farklılaşacağını öngören Hipotez 3'tür. Kişi-iş uyumu ve algılanan yönetici desteğinin işe bağlanma üzerindeki düzenleyici etkisine ait regresyon analizi sonuçları Tablo 4'te verilmiştir. 
Eskişehir Osmangazi Üniversitesi IißBF Dergisi

Tablo 4. Kişi-iş uyumu ve Işse Bağlanma ilişskisinde Algılanan Yönetici Desteğinin Düzenleyici Etkisine ilişkin Sonuçlar

\begin{tabular}{|c|c|c|c|c|}
\hline \multirow{2}{*}{ Adımlar } & \multirow{2}{*}{ Değişkenler } & \multicolumn{3}{|l|}{ İşe Bağlanma } \\
\hline & & $\beta(p)$ & $R^{2}$ (Düzeltilmiş $R^{2}$ ) & $\bar{F}$ \\
\hline \multirow{4}{*}{1} & Cinsiyet & $-.008(.819)$ & \multirow{4}{*}{$.022(.008)$} & \multirow{4}{*}{1.560} \\
\hline & Yaş & $.001(.983)$ & & \\
\hline & Medeni Hal & .001 (.979) & & \\
\hline & Eğitim & $-.045(.186)$ & & \\
\hline \multirow{2}{*}{2} & Kişi-iş uyumu (KiU) & $.390(.000)$ & \multirow{2}{*}{$.678(.671)$} & \multirow{2}{*}{95.819} \\
\hline & Algılanan yönetici desteği (AYD) & $.514(.000)$ & & \\
\hline 3 & KIUXAYD & $-.082(.018)$ & $.685(.676)$ & 84.337 \\
\hline
\end{tabular}

Tablo 4'teki sonuçlara bakıldığında kişi-iş uyumu ile algılanan yönetici desteği etkileşiminin (KiUXAYD) işe bağlanma üzerindeki etkisinin anlamlı olduğu ( $\beta=-.082 ; p<.05)$, dolayısıyla Hipotez 3'ün desteklendiği söylenebilir (Preacher vd., 2007).

Araştırma kapsamında incelenen son hipotez, iş özerkliğinin kişi-iş uyumu aracıllğı ile işe bağlanma üzerindeki dolaylı etkisi ve bu etkide algılanan yönetici desteğinin düzenleyici etkisinin olduğu yönündeki Hipotez 4'tür. Bu hipotezin test edilmesi için Preacher ve Hayes (2004) tarafından geliştirilen SPSS macro programı kullanılmıştır. Bu program, önerilen Bootstrapping metodunun uygulanmasını kolaylaştııı ve düzenleyici değişkeninin farklı seviyelerindeki şartlı dolaylı etkilerin önemini tespit etmemizi sağlar (Cole vd., 2008). Şartlı dolaylı etki ile ilgili yapılan çalışmalar (Muller vd., 2005; Preacher vd., 2007; Edwards ve Lambert, 2007), bu etkinin varlığı için bazı şartların sağlanması gerektiğini iddia ederler. Bu şartlardan ilki iş özerkliğinin işe bağlanma üzerindeki etkisinin anlamlı olması gerektiğidir. Bu şart Tablo 3 'te verilen değerlere göre (birinci sütun ikinci adım) sağlanmıştır ( $\beta=.531 ; p<.01)$. Ikinci şart olan kişi-iş uyumu ile algılanan yönetici desteği etkileşiminin işe bağlanma üzerindeki etkisinin anlamlı olması yönündedir (Muller vd., 2005). Bu şartın sağlandığı Tablo 4'teki sonuçlar incelendiğinde görülmektedir ( $\beta=$ -.082; $p<.05)$. Üçüncü şart kişi-iş uyumu ile işe bağlanma ilişkisinin anlamlı olması gerektiğini vurgular. Bu şartın sağlandığı Tablo 3'te birinci sütunda üçüncü adımdaki sonuçlardan anlaşılmaktadır ( $\beta=.708 ; p<.01$ ). Son şart, iş özerkliğinin işe bağlanma üzerindeki kişi-iş uyumu aracılığıyla aktarılan dolaylı etkisinin algılanan yönetici desteğinin düşük ve yüksek seviyelerine göre değişmesi gerektiği yönündedir. Bu şartın sağlanıp sağlanmadığını test etmek için yapılan analiz sonuçları Tablo 5 'te verilmiştir.

Tablo 5. İ̧ Özerkliği, Kişi-iş Uyumu ve Işse Bağlanma Arasındaki Ilişskide Algılanan Yönetici Desteğinin Şartlı Dolaylı Etkisine Ilişkin Sonuçlar

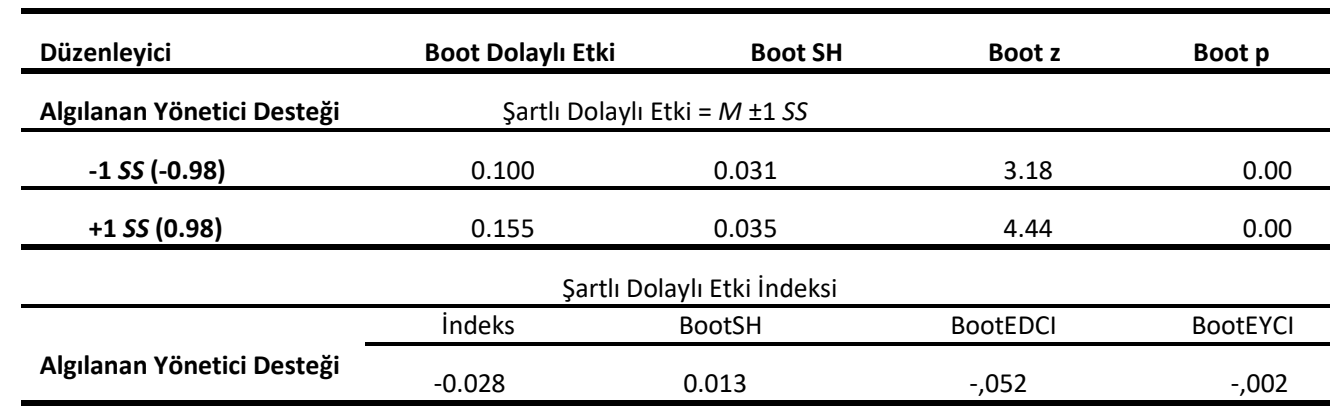


Tablodaki sonuçlar incelendiğinde algılanan yönetici desteğinin yüksek olduğu seviyelerde iş özerkliği ile işe bağlanma arasındaki ilişkide kişi-iş uyumunun dolaylı etkisinin güçlü $(\beta=.155$; $p<.01)$, düşük olduğu seviyelerde ise zayıf olduğu görülmektedir $(\beta=.100 ; p<.01)$. Bu sonuçlar doğrultusunda Hipotez 4'ün desteklendiği söylenebilir.

Kişi-iş uyumunun işe bağlanma üzerindeki etkisinin algılanan yönetici desteğinin farklı seviyelerine göre değişkenlik gösterip göstermediği Aiken ve West'in (1991) eğim testi ile analiz edilmiş ve sonuçlar Şekil 2'de verilmiştir. Şekilde algılanan yönetici desteğinin artması durumunda kişi-iş uyumu ile işe bağlanma ilişkisinin güçlendiği, azaldığı durumda ise zayıfladığı görülmektedir.

Şekil 2. Kişi-Iş Uyumu ile Işe Bağlanma iliş̧isinde Algılanan Yönetici Desteğinin Düzenleyici Etkisi

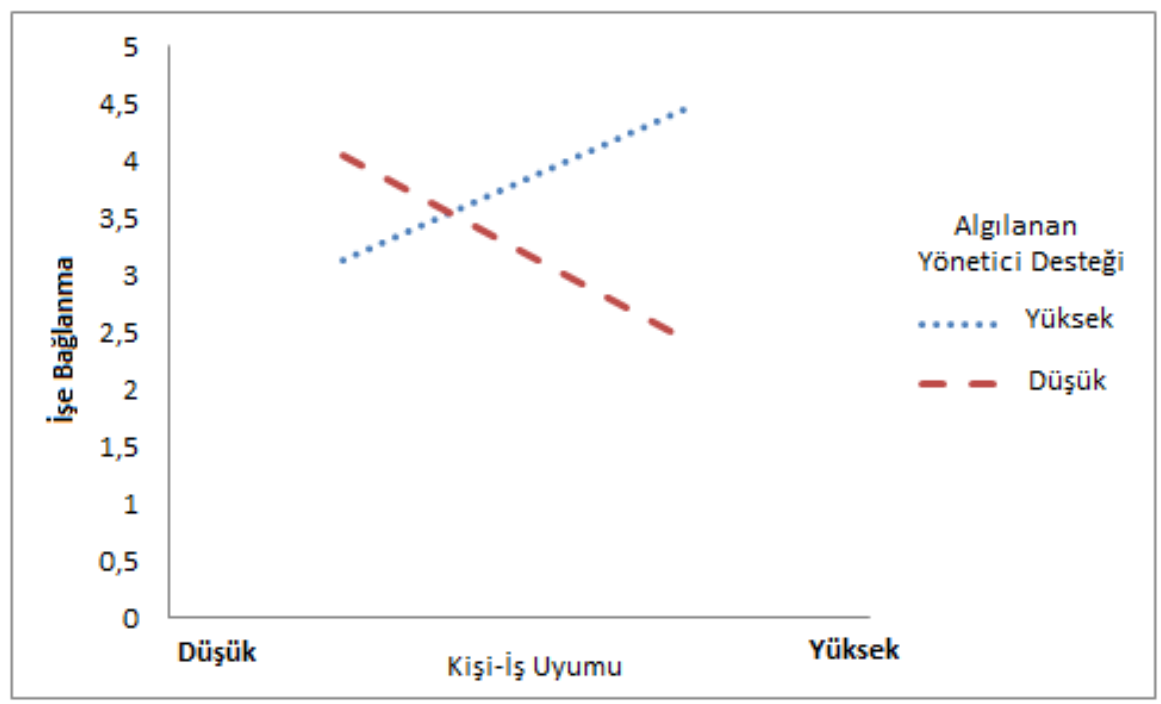

\section{Sonuç}

Bu çalışmanın amacı, iş özerkliğinin kişi-iş uyumu aracılığıyla işe bağlanma üzerindeki etkisinde algılanan yönetici desteğinin düzenleyici etkisinin tespit edilmesidir. Çalışma bulguları iş özerkliği ve işe bağlanma ilişkisinde kişi-iş uyumunun aracı etkisinin olduğunu desteklemiştir. Ayrıca kişi-iş uyumunun işe bağlanma üzerindeki etkisinin algılanan yönetici desteğinin farklı seviyelerine göre değiştiği ispatlanmıştır. Algılanan yönetici desteğinin yüksek olduğu durumlarda kişi-iş uyumunun işe bağlanma üzerindeki etkisi güçlü iken, düşük olduğunda zayıf olmaktadır. Sonuçlar ayrıca, iş özerkliğinin işe bağlanma üzerindeki (kişi-iş uyumu aracılığıyla aktarılan) dolaylı etkisinin algılanan yönetici desteği yüksek iken güçlü, düşük iken zayıf olduğunu göstermiştir. Yapılan analizlerin birtakım teorik ve pratik etkileri aşağıda tartışımıştır.

Araştırma bulguları doğrultusunda birtakım teorik etkiler ortaya çıkmıştır. Bulguların birinci teorik etkisi iş özerkliği, kişi-iş uyumu ve işe bağlanma ilişkisine açıklık getirmesidir. Araştırma sonuçları iş özerkliğinin işe bağlanmanın önemli bir öncülü olduğunu savunan araştırmalara (Kahn, 1990; Hallberg ve Schaufeli, 2006; Saks, 2006; Hallberg vd., 2007; SheeMun vd., 2013; Lin ve Ping, 2016; Vera vd., 2016; Orth ve Volmer, 2017; Malinowska vd., 2018; Tummers vd., 2018) kişi-iş uyumunun da bu ilişkide önemli bir faktör olduğu yönünde katkı yapması açısından önemlidir. Ayrıca bu çalışma bulguları Kahn'ın (1990) iş özerkliğinin işe bağlanmayı etkileyen boyutlardan biri olduğu iddiasını desteklemektedir. 
Vera vd. (2016) hemşirelerin yaptıkları işte özerk olmalarının yaptıkları işe bağlanmalarını pozitif etkilediğini, öte yandan yöneticilerin sosyal desteğinin artmasının bu etkiyi güçlendirdiğini tespit etmişlerdir. Bu çalışma sonuçları Vera ve arkadaşları tarafından yapılan çalışma sonuçlarını desteklemekle birlikte, farklı değişkenlerin de bu ilişkide etkili olduğunu ortaya koyması açısından bu çalışmaya katkıda bulunmuştur. Bu çalışma sonuçları daha önceki çalışma sonuçlarını desteklemekle birlikte kişi-iş uyumunun da bu ilişkide önemli bir aktör olduğunu ortaya koymaktadır. Yongxing vd. (2017) işe bağlanmanın performans üzerindeki etkisinin algılanan yönetici desteğinin seviyesine göre farklılaştığını tespit etmiştir. Bu çalışma, işe bağlanmanın sonuçları ile ilgili yapılan çalışmalara (örneğin Yongxing vd. 2017; Warr ve İnceoğlu, 2012; Geldenhuys vd., 2014; Lisbona vd., 2018) işe bağlanmanın öncülleri (iş̧ özerkliği ve kişi-iş uyumu) hakkında bilgi vermesi anlamında katkı yaptığı söylenebilir.

Algılanan yönetici desteği, yöneticinin çalışanın yapmış olduğu katkıya verdiği değerin ve çalışanın refahına yaptığı katkının çalışan tarafından hissedilme derecesidir (Eisenberger vd., 2002). Bu araştırma bulguları yöneticilerin yeterince destek sağladığını algılayan çalışanların işlerine daha fazla bağlandıklarını ortaya koyması açısından algılanan yönetici desteği literatürüne katkıda bulunmuştur. Algılanan yönetici desteği literatüründen yola çıkarak, algılanan yönetici desteğinin kişi-iş uyumu ile işe bağlanma arasındaki ilişkide düzenleyici olarak modele dahil edilerek test edilmiştir. Yapılan analizler sonucunda algılanan yönetici desteğinin kişi-iş uyumunun işe bağlanma üzerindeki etkisinde önemli bir belirleyici olduğu görülmüştür. Bu çaIışma, algılanan yönetici desteğinin düzenleyici etkisini test ederek, kişi-iş uyumu ve işe bağlanma ilişkisine yönelik yapılan çalışmaların (Lu vd., 2014; Sulistiowati vd., 2018; Rahmadani ve Sebayang, 2017; Hamid ve Yahya, 2016; Memon vd., 2015; Warr ve İnceoğlu, 2012) daha iyi anlaşılmasına katkıda bulunmuştur.

Araştırma sonuçlarının teorik etkilerinin yanında yöneticiler ve örgütler için de birtakım etkileri vardır. Birçok araştırmacı kişi-iş uyumunun işe alım süreçlerinin seçme aşamasında dikkat edilmesi gerektiğine vurgu yapmıştır (Kristof-Brown, 2000; Sekiguchi, 2004; Carless, 2005; Peltokangas, 2016). Araştırma bulguları, çalışanların işe alındıktan sonra (işlerini yaparken) sahip oldukları iş özerkliğinin işe bağlanmaları üzerindeki etkisinde, işe alım öncesinde insan kaynakları departmanının dikkat etmesi gereken kişi-iş uyumunun önemini vurgulaması açısından önemlidir. Sekiguchi'ye (2011) göre çalışanların işleriyle uyumları yöneticilerin iş karakteristiklerini dikkatte almaları sayesinde artırılabilir. Bu çalışma sonuçları iş karakteristiklerinden biri olan iş özerkliğinin artmasının çalışanların işleriyle uyumlarını artırdığını ortaya koyması açısından Sekiguchi'nin (2011) iddiasını desteklemektedir.

Saks'a (2006) göre çalışanlara yaptıkları işte daha fazla özerklik ve destek vermek onların işe bağlanmalarını artırır. Bu çalışma sonuçları özerkliğin kişi-iş uyumu aracılı̆̆ıyla işe bağlanma üzerindeki etkisinin yönetici desteğine göre farklılaştığını ortaya koymasından ötürü Saks'ın iddiasını desteklemektedir. Bu sonuçlar çalışanların işe bağlanmasında yöneticilerin desteği yanında insan kaynakları uygulamalarının da önemli olduğuna vurgu yapmaktadır. Boon vd. (2011) tarafından yapılan araştırma sonuçlarına göre çalışanların işleriyle uyumlarında insan kaynakları uygulamalarının önemli bir belirleyici olduğu tespit edilmiştir. Gerek hizmet gerekse üretim sektörü olsun bütün işletmeler işine bağlanmamış çalışanlardan şikayetçilerdir (ibrahim vd., 2019). Bu nedenle işletmeler çalışanların işlerine bağlanmalarını artırmak için insan kaynakları uygulamalarını gözden geçirerek gerekli iyileştirmeleri yapmaları gerekir. Örneğin işletme yöneticileri iş özerkliğini artırıcı iş tasarımlarını yaparak, adil bir ödüllendirme sistemini oluşturarak, esnek çalışma saatlerini uygulayarak, eğitim olanaklarını artırarak ve kariyer geliştirme 
desteği vererek çalışanların işlerine bağlanmalarını artırabilirler (Saks, 2006). Ayrıca insan kaynaklarının iş analizlerini dikkatli bir şekilde yapması ve aday arama, bulma ve seçme süreçlerini gözden geçirerek geliştirmesi işe uygun çalışanların alınmasını sağlayacaktır.

Araştırma bulguları her ne kadar literatüre ve sektör yöneticilerinin alacakları kararlara katkı yapsa da, araştırma birtakım kısıtlılıklar dâhilinde gerçekleştirilmiştir. Bu kısıtlılıklardan ilki araştırmanın kesitsel (cross-sectional) bir çalışma olmasından ötürü araştırma sonuçlarının nedenselliği ile ilgili yeterli bilgi verilememesidir. Araştırma sonuçlarının nedensel etkileri ile ilgili daha kesin sonuçlar elde etmek için boylamsal çalışmalara ihtiyaç vardır. Bu nedenle gelecekteki çaIışmalar araştırma verilerini boylamsal olarak elde ederek neden sonuç ilişkisine daha iyi vurgu yapabilirler (Robins, 1997). Araştırmanın ikinci kısıtı bağımlı değişken olan işe bağlanmanın artması durumunda sonuçlarının ne olacağı hakkındaki iş çıktılarının modele dâhil edilmemiş olmasıdır. Hallberg ve Schaufeli (2006) işe bağıılığı artan çalışanların örgüte bağlılıklarının artacağını ve işten ayrılma niyetlerinin azalacağını tespit etmiştir. Gelecekteki araştırmalar farklı değişkenleri (örneğin performans, örgütsel vatandaşlık davranışı, örgüte bağııık, işten ayrılma niyeti) de bağımlı değişken olarak modele dâhil ederek bu araştırma sonuçlarını genişletebilirler. Araştırmanın üçüncü kısıtı araştırma verilerinin Türkiye'de hizmet sektöründe faaliyet gösteren iki firmanın çalışanlarından elde edilmiş olmasıdır. Araştırma bulgularının genellenebilmesi için farklı sektördeki çalışanlara uygulanması gerekmektedir. 


\section{Eskişehir Osmangazi Üniversitesi IïB Dergisi}

\section{Kaynaklar}

Adebayo, Sulaiman Olanrewaju; Ifenna D. Ezeanya (2011). "Task Identity and Job Autonomy as Correlates of Burnout among Nurses in Jos, Nigeria." International Review of Social Sciences and Humanities, Vol. 2, No. 1: 7-13.

Aiken, Leona S.; Stephen G. West; Raymond R. Reno (1991), Multiple Regression: Testing and Interpreting Interactions. Newbury Park, CA: Sage Publication.

Babakus, Emin; Ugur Yavas; Nicholas J. Ashill (2010), "Service Worker Burnout and Turnover Intentions: Roles of PersonJob Fit, Servant Leadership, and Customer Orientation", Services Marketing Quarterly, Vol. 32, No. 1: 17-31.

Babbie, Earl (2001). The Practice of Social Research. 9th Edition, Wadsworth Thomson, Belmont.

Bakker, Arnold B.; Evangelia Demerouti. "Towards a Model of Work Engagement." Career Development International.

Ballantine, Kim; Christopher G. Nunns (1998), "The Moderating Effect of Supervisory Support on the Self-Efficacy WorkPerformance Relationship", South African Journal of Psychology, Vol. 28, No. 3: 164-173.

Baron, Reuben M.; David A. Kenny. (1986). "The Moderator-Mediator Variable Distinction in Social Psychological Research: Conceptual, Strategic, and Statistical Considerations." Journal of Personality and Social Psychology, Vol. 51, No.6: 1173-1182.

Boon, Corine, et al. (2011), "The Relationship between Perceptions of HR Practices and Employee Outcomes: Examining the Role of Person-Organisation and Person-Job Fit", The International Journal of Human Resource Management, Vol. 22, No. 01: 138-162.

Brkich, Mariana, Danielle Jeffs; Sally A. Carless (2002). "A Global Self-Report Measure of Person-Job Fit." European Journal of Psychological Assessment, Vol. 18, No. 1: 43-51.

Carless, Sally A. (2005), "Person-Job Fit Versus Person-Organization Fit as Predictors of Organizational Attraction and Job Acceptance Intentions: A Longitudinal Study", Journal of Occupational and Organizational Psychology, Vol. 78, No. 3: 411-429.

Chhabra, Bindu (2015), "Person-Job Fit: Mediating Role of Job Satisfaction \& Organizational Commitment", the Indian Journal of Industrial Relations, 638-651.

Christian, Michael S., Adela S. Garza; Jerel E. Slaughter (2011). "Work engagement: A Quantitative Review and Test of Its Relations with Task and Contextual Performance." Personnel Psychology, Vol. 64, No. 1: 89-136.

Cole, Michael S., Frank Walter; Heike Bruch (2008). "Affective Mechanisms Linking Dysfunctional Behavior to Performance in Work Teams: A Moderated Mediation Study." Journal of Applied Psychology, Vol. 93, no. 5: 945-958.

Dawis, Rene, V.; George, England; Lloyd, H. Lofquist (1964), "A Theory of Work Adjustment (Minnesota Studies in Vocational Rehabilitation: XV, Under Support of the US Department of Health, Education, and Welfare). Minneapolis: University of Minnesota". Industrial Relations Center.

Demerouti, Evangelia, et al. (2001). "Burnout and Engagement at Work as a Function of Demands and Control." Scandinavian Journal of Work, Environment \& Health, Vol. 27, No. 4: 279-286.

DeConinck, James B.; Julie T. Johnson,(2009), "The Effects of Perceived Supervisor Support, Perceived Organizational Support, and Organizational Justice on Turnover among Salespeople", Journal of Personal Selling \& Sales Management, Vol. 29, No. 4: 333-350.

Diekmann, Andreas (2004), "The Power of Reciprocity: Fairness, Reciprocity, and Stakes in Variants of the Dictator Game", Journal of Conflict Resolution, Vol. 48, No. 4: 487-505.

Dysvik, Anders; Bård Kuvaas (2013), "Perceived Job Autonomy and Turnover Intention: The Moderating Role of Perceived Supervisor Support", European Journal of Work and Organizational Psychology, Vol. 22, No. 5: 563-573.

Edwards, Jeffrey R. (1991), Person-Job Fit: A Conceptual Integration, Literature Review, and Methodological Critique. New York: John Wiley \& Sons.

Edwards, Jeffrey R.; Lisa Schurer Lambert (2007). "Methods for Integrating Moderation and Mediation: A General Analytical Framework Using Moderated Path Analysis." Psychological Methods, Vol. 12, No. 1: 1-22.

Eisenberger, Robert, et al. (2002). "Perceived supervisor Support: Contributions to Perceived Organizational Support and Employee Retention." Journal of Applied Psychology, Vol. 87, No. 3: 565-573.

Galletta, Maura, Igor Portoghese; Adalgisa Battistelli (2011). "Intrinsic Motivation, Job Autonomy and Turnover Intention in the Italian Healthcare: The Mediating Role of Affective Commitment." Journal of Management Research, Vol. 3, No. 2: 1-19. 
Geldenhuys, Madelyn; Karolina Laba; Cornelia M. Venter (2014), "Meaningful Work, Work Engagement and Organisational Commitment", SA Journal of Industrial Psychology, Vol. 40, No. 1: 01-10.

Gillet, Nicolas, et al. (2013). "The Role of Supervisor Autonomy Support, Organizational Support, and Autonomous and Controlled Motivation in Predicting Employees' Satisfaction and Turnover Intentions." European Journal of Work and Organizational Psychology, Vol. 22, No. 4: 450-460.

Goffman, Erving (1961), Encounters: Two Studies in the Sociology of Interaction. Ravenio Books.

Gouldner, Alvin W. (1960)."The Norm of Reciprocity: A Preliminary Statement." American Sociological Review, Vol. 25, No. 2: 161-178.

Guan, Yanjun, et al. (2010), "Person-Job Fit and Work-Related Attitudes among Chinese Employees: Need for Cognitive Closure as Moderator", Basic and Applied Social Psychology, Vol. 32, No. 3: 250-260.

Hackman, J. Richard; Edward E. Lawler (1971). "Employee Reactions to Job Characteristics." Journal of Applied Psychology, Vol. 55, No. 3 (1971): 259.

Hackman, J. Richard; Oldham, Greg R. (1976). "Motivation through the Design of Work: Test of a Theory." Organizational Behavior and Human Performance, Vol. 16, No. 2: 250-79.

Hackman, J. Richard; Oldham, Greg R. (1980). "Work redesign." Canada: Addison-Wesley Publications.

Hallberg, Ulrika E.; Wilmar B. Schaufeli (2006). "Same Same” but Different? Can Work Engagement be Discriminated from Job Involvement and Organizational Commitment?." European Psychologist, Vol. 11, No. 2: 119-127.

Hallberg, Ulrika E.; Gunn Johansson; Wilmar B. Schaufeli (2007), "Type A behavior and work situation: Associations with burnout and work engagement", Scandinavian Journal of Psychology, Vol. 48, No. 2: 135-142.

Hamid, Siti Norasyikin Abdul; Khulida Kirana Yahya (2016), "Mediating Role of Work Engagement on the Relationship between Person-Job Fit and Employees' Retention: Evidence from Semiconductor Companies in Northern Region of Malaysia", International Review of Management and Marketing, Vol. 6, No. 7S: 187-194.

Hooper, Narelle (2006). Companies where people want to work. The Australian Financial Review, March, 4-5.

Ibrahim; Siti Nur Hidayah; Choo Ling Suan; Osman M. Karatepe (2019), "The Effects of Supervisor Support and SelfEfficacy on Call Center Employees' Work Engagement and Quitting Intentions", International Journal of Manpower.

Idris, Mohd Awang; Maureen F. Dollard (2011), "Psychosocial Safety Climate, Work Conditions, and Emotions in the Workplace: A Malaysian Population-Based Work Stress Study", International Journal of Stress Management, Vol. 18, No. 4: 324-347.

Iqbal, Muhammad Tahir; Waqas Latif; Wahab Naseer (2012), "The Impact of Person Job Fit on Job Satisfaction and Its Subsequent Impact on Employees Performance", Mediterranean Journal of Social Sciences, Vol. 3, No. 2: 523-530.

Jacobs, Holly (2013). "An Examination of Psychological Meaningfulness, Safety, and Availability as the Underlying Mechanisms Linking Job Features and Personal Characteristics to Work Engagement." FIU Electronic Theses and Dissertations. 904.

June, Sethela; Rosli Mahmood (2011), "The Relationship between Person-Job Fit and Job Performance: A Study among the Employees of the Service Sector SMEs in Malaysia", International Journal of Business, Humanities and Technology, Vol. 1, No. 2: 95-105.

Kahn, William A. (1990). "Psychological Conditions of Personal Engagement and Disengagement at Work." Academy of Management Journal, Vol. 33, No. 4: 692-724.

Kalidass, Anneswary; Arsiah Bahron (2015), "The Relationship between Perceived Supervisor Support, Perceived Organizational Support, Organizational Commitment and Employee Turnover Intention", International Journal of Business Administration, Vol. 6 No. 5: 82-89.

Karasek Jr, Robert A. (1979), "Job Demands, Job Decision Latitude, and Mental Strain: Implications for Job Redesign", Administrative Science Quarterly, 24: 285-308.

Kataria, Aakanksha, Pooja Garg; Renu Rastogi (2013). "Employee Engagement and Organizational Effectiveness: The Role of Organizational Citizenship Behavior." International Journal of Business Insights \& Transformation, Vol. 6, No. 1: 102-113.

Kerse, Gökhan. (2018). "The Impact of Job Crafting on Person-Job Fit:“I Am Compatible with My Work Because I Can Make Changes in My Work". Atatürk Üniversitesi Iktisadi ve Idari Bilimler Dergisi, C.32, S.4: 941-958.

Kerse, Gökhan.; Karabey, Canan Nur (2019). "Örgütsel Sinizm ve Özdeşleşme Bağlamında Algılanan Örgütsel Desteğin İşe Bağlanma ve Politik Davranış Algısına Etkisi”. Eskişehir Osmangazi Üniversitesi Iktisadi ve Idari Bilimler Dergisi, C. 14, S. 1: 83-108. 


\section{Eskişehir Osmangazi Üniversitesi IïB Dergisi}

Kim, Hyun Jeong, et al. (2017), "Is All Support Equal? The Moderating Effects of Supervisor, Coworker, and Organizational Support on the Link between Emotional Labor and Job Performance", BRQ Business Research Quarterly, Vol. 20, No. 2: 124-136.

Kristof-Brown, Amy L.; Ryan D. Zimmerman; Erin C. Johnson (2005), "Consequences of Individuals' Fit at Work: A MetaAnalysis of Person-Job, Person-Organızatıon, Person-Group, and Person-Supervisor Fit", Personnel Psychology, Vol. 58, No. 2: 281-342.

Leiter, Michael P.; Arnold B. Bakker (2010). "Work Engagement: Introduction." Work Engagement: A Handbook of Essential Theory and Research, 1-9.

Leng, Goh Ee; Michelle Lee Chin Chin (2016), "Person-Job Fit, Personality, Organizational Commitment and Intention to Stay among Employees in Marketing Departments", Jurnal Psikologi Malaysia, Vol. 30, No.1: 80-89.

Lin, Jocelyn Tang Phaik; Nicole Chen Lee Ping (2016), "Perceived Job Autonomy and Employee Engagement as Predictors of Organizational Commitment", Undergraduate Journal of Psychology, Vol. 29, No. 1: 1-16.

Ling Suan, Choo; Aizzat Mohd Nasurdin (2016), "Supervisor Support and Work Engagement of Hotel Employees in Malaysia: Is it Different for Men and Women?", Gender in Management: An International Journal, Vol. 31, No. 1: 218.

Lisbona, Ana, et al. (2018), "The Effects of Work Engagement and Self-Efficacy on Personal Initiative and Performance", Psicothema, Vol. 30, No. 1: 89-96.

Lu, Chang-qin, et al. (2014), "Does Work Engagement Increase Person-Job Fit? The Role of Job Crafting and Job Insecurity", Journal of Vocational Behavior, Vol. 84, No. 2: 142-152.

MacKinnon, David P., et al. (2002), "A Comparison of Methods to Test Mediation and Other Intervening Variable Effects", Psychological Methods, Vol. 7, No. 1: 83-104.

Maertz Jr, Carl P., et al. (2007), "The Effects of Perceived Organizational Support and Perceived Supervisor Support on Employee Turnover", Journal of Organizational Behavior: The International Journal of Industrial, Occupational and Organizational Psychology and Behavior, Vol. 28, No. 8: 1059-1075.

Malinowska, Diana, Aleksandra Tokarz; Anna Wardzichowska (2018). "Job Autonomy in Relation to Work Engagement and Workaholism: Mediation of Autonomous and Controlled Work Motivation." International Journal of Occupational Medicine and Environmental Health, Vol. 31, No. 4: 445-458.

Maslach, Christina, Wilmar B. Schaufeli; Michael P. Leiter (2001). "Job Burnout." Annual Review of Psychology, Vol. 52, No. 1: 397-422.

Memon, Mumtaz Ali; Rohani Salleh; Mohamed Noor Rosli Baharom, (2015), "Linking Person-Job Fit, Person-Organization Fit, Employee Engagement and Turnover Intention: A Three-Step Conceptual Model", Asian Social Science, Vol. 11, No. 2: 313-320.

Morgeson, Frederick P., Kelly Delaney-Klinger; Monica A. Hemingway (2005). "The Importance of Job Autonomy, Cognitive Ability, and Job-Related Skill for Predicting Role Breadth and Job Performance." Journal of Applied Psychology, Vol. 90, No. 2: 399-406.

Muller, Dominique, Charles M. Judd; Vincent Y. Yzerbyt (2005). "When Moderation is Mediated and Mediation is Moderated." Journal of Personality and Social Psychology, Vol. 89, No. 6: 852-863.

Naqvi, S. R., et al. (2013). "Impact of Job Autonomy on Organizational Commitment: Moderating Role of Job Satisfaction in Tobacco Industry of Pakistan." Far East Journal of Psychology and Business, Vol. 12, No. 5: 57-72.

Nguyen A. N., Taylor, Jim; Steve Bradley (2003). "Job Autonomy and Job Satisfaction: New Evidence." Department of Economics, Management School Lancaster University Lancaster, England.

O'Reilly III, Charles A.; Jennifer Chatman; David F. Caldwell (1991), "People and Organizational Culture: A Profile Comparison Approach to Assessing Person-Organization Fit", Academy of Management Journal, Vol. 34, No. 3: 487516.

Orth, Maximilian; Judith Volmer (2017). "Daily Within-Person Effects of Job Autonomy and Work Engagement on Innovative Behaviour: The Cross-Level Moderating Role of Creative Self-Efficacy." European Journal of Work and Organizational Psychology, Vol. 26, No. 4: 601-612.

Peltokangas, Hanna (2016), "Job-Person Fit and Leader's Performance: The Moderating Effect of the Rorschach Comprehensive System Variables", Asian Journal of Social Sciences and Management Studies, Vol. 3, No. 1: 18-28.

Podsakoff, Philip M., et al. (2003). "Common Method Biases in Behavioral Research: A Critical Review of the Literature and Recommended Remedies." Journal of Applied Psychology, Vol. 88, No. 5: 879-903. 
Podsakoff, Philip M., Scott B. MacKenzie; Nathan P. Podsakoff (2012). "Sources of Method Bias in Social Science Research and Recommendations on How to Control It." Annual Review of Psychology, Vol. 63: 539-569.

Pramudita, Annisa; B. Munir Sukoco (2018), "The Moderating Roles of Perceived Supervisor Support between Psychological Contract and Job-related Outcomes", KnE Social Sciences, Vol. 3, No. 10.

Preacher, Kristopher J.; Andrew F. Hayes (2004), "SPSS and SAS Procedures for Estimating Indirect Effects in Simple Mediation Models", Behavior Research Methods, Instruments, \& Computers, Vol. 36, No. 4: 717-731.

Preacher, Kristopher J., Derek D. Rucker; Andrew F. Hayes (2007). "Addressing Moderated Mediation Hypotheses: Theory, Methods, and Prescriptions." Multivariate Behavioral Research, Vol. 42, No. 1: 185-227.

Rafferty, Yvonne, Ronald Friend; Paul A. Landsbergis (2001). "The Association between Job Skill Discretion, Decision Authority and Burnout." Work \& Stress, Vol. 15, No. 1: 73-85.

Rahmadani, Vivi Gusrini; Indah Rasulinta Sebayang (2017), "The Influence of Person-Organization Fit and Person-Job Fit on Work Engagement among Policemen in Sumatera Utara", International Journal of Management Science and Business Administration, Vol. 4, No. 1: 45-51.

Robins, James M. (1997), Causal Inference from Complex Longitudinal Data, Latent Variable Modeling and Applications to Causality. New York: Springer.

Rhoades, Linda, Robert Eisenberger; Stephen Armeli (2001). "Affective commitment to the Organization: The Contribution of Perceived Organizational Support." Journal of Applied Psychology, Vol. 86, No. 5: 825-836.

Rich, Bruce Louis, Jeffrey A. Lepine; Eean R. Crawford (2010). "Job Engagement: Antecedents and Effects on Job Performance." Academy of Management Journal, Vol. 53, No. 3: 617-635.

Saks, Alan M. (2006), "Antecedents and Consequences of Employee Engagement", Journal of Managerial Psychology, Vol. 21, No. 7: 600-619.

Schaufeli, Wilmar B., et al. (2002). "The Measurement of Engagement and Burnout: A Two Sample Confirmatory Factor Analytic Approach." Journal of Happiness Studies, Vol. 3, No. 1: 71-92.

Schaufeli, Wilmar B., Arnold B. Bakker; Marisa Salanova (2006). "The Measurement of Work Engagement with a Short Questionnaire: A Cross-National Study." Educational and Psychological Measurement, Vol. 66, No. 4: 701-716.

Schaufeli, Wilmar B. (2013), What is Engagement? Employee Engagement in Theory and Practice. London: Routledge.

Scroggins, Wesley A. (2008), "Antecedents and Outcomes of Experienced Meaningful Work: A Person-Job Fit Perspective", the Journal of Business Inquiry, Vol. 7, No. 1: 68-78.

Sekiguchi, Tomoki (2004). "Person-Organization Fit and Person-Job Fit in Employee Selection: A Review of the Literature", Osaka Keidai Ronshu, Vol. 54, No. 6: 179-196.

SheeMun, Yong, et al. (2013), "Employee Engagement: A Study from the Private Sector in Malaysia", Human Resource Management Research, Vol. 3, No. 1: 43-48.

Sia, Surendra Kumar; Bharat Chandra Sahoo; Pravakar Duari (2010), "Gender Discrimination and Work Engagement: Moderating Role of Future Time Perspective", South Asian Journal of Human Resources Management, Vol. 2, No. 1: 58-84.

Sisodia, Shalini; Ira Das (2013). "Effect of job autonomy upon organizational commitment of employees at different hierarchical level." Psychological Thought, Vol. 6, No. 2: 241-251.

Spector, Paul E. (2006), "Method Variance in Organizational Research: Truth or Urban Legend?", Organizational Research Methods, Vol. 9, No. 2: 221-232.

Stephens, Carlie A. (2016), The Moderating Role of Perceived Organizational Support and Perceived Supervisor Support on the Relationship Between Teamwork Behaviors and Affective Commitment, Published Master's Thesis.

Sulistiowati, Sulistiowati; Nurul Komari; Endang Dhamayanti (2018), "The Effects of Person-Job Fit on Employee Engagement Among Lecturers in Higher Education Institutions: Is There a Difference between Lecturers in Public and Private Higher Education Institutions?", International Review of Management and Marketing, Vol. 8, No. 3: 75-80.

Torraco, Richard J. (2005), "Work design Theory: A Review and Critique with Implications for Human Resource Development," Human Resource Development Quarterly, Vol. 16, No. 1: 85-109.

Tummers, Lars G.; Laura Den Dulk (2013). "The Effects of Work Alienation on Organisational Commitment, Work Effort and Work-To-Family Enrichment." Journal of Nursing Management, Vol. 21, No. 6: 850-859.

Van Wijhe, Corine, et al. (2011), "Understanding Workaholism and Work Engagement: The Role of Mood and Stop Rules", Career Development International, Vol. 16, No. 3: 254-270. 


\section{Eskişehir Osmangazi Üniversitesi IïB Dergisi}

Vera, María, et al. (2016), "The Role of Co-Worker and Supervisor Support in The Relationship between Job Autonomy and Work Engagement among Portuguese Nurses: A Multilevel Study", Social Indicators Research, Vol. 126, No. 3: 1143-1156.

Wampold, Bruce E.; Richard D. Freund (1987), "Use of Multiple Regression in Counseling Psychology Research: A Flexible Data-Analytic Strategy", Journal of Counseling Psychology, Vol. 34, No. 4: 372-382.

Wang, Zhongmin (2014), "Perceived Supervisor Support and Organizational Citizenship Behavior: The Role of Organizational Commitment", International Journal of Business and Social Science, Vol. 5, No. 1: 210-214.

Warr, Peter; Ilke Inceoglu (2012), "Job Engagement, Job Satisfaction, and Contrasting Associations with Person-Job Fit", Journal of Occupational Health Psychology, Vol. 17, No. 2: 129-151.

Yongxing, Guo, et al. (2017), "Work Engagement and Job Performance: The Moderating Role of Perceived Organizational Support", Anales de Psicología/Annals of Psychology, Vol. 33, No. 3: 708-713.

Zhao, Xinshu, John G. Lynch Jr, and Qimei Chen (2010), "Reconsidering Baron and Kenny: Myths and Truths about Mediation Analysis", Journal of Consumer Research, Vol. 37, No. 2: 197-206. 
I proposed and tested a moderated mediation model that examines person-job fit as the mediator and perceived supervisor as the moderator in relationships between job autonomy and job engagement. This study aims to determine whether the indirect effect of job autonomy on job engagement (through person-work cohesion) varies according to the level of perceived supervisor support. Thus, it is aimed to contribute to the literature on the antecedent of personjob fit and job engagement and the results of job autonomy and supervisor support. For this purpose, four hypotheses were developed. The first of these hypotheses assume that job autonomy is positively associated with person-job fit. The second hypothesis of the study is that the person-job fit has a mediating effect on the relationship between job autonomy and job engagement. The third hypothesis is that the positive effect of person-job fit on job engagement is strong when perceived supervisor support increases, and weak when it decreases. Finally, in the fourth hypothesis of the research, it was claimed that the positive and indirect effect of job autonomy on job engagement (through personjob fit) is strong when perceived executive support is high and weak when it is low.

Many factors affect employee engagement (e.g. organizational support, feedback, organizational justice). Job autonomy, which is related to the level of freedom and independence that individuals have while doing their jobs, is one of the factors affecting job engagement. When the studies claiming that work autonomy is an important determinant of job engagement are examined, it is seen that the fit of the employees with their job (person-job fit) is ruled out. Some researchers who have investigated the effect of job autonomy on job engagement have suggested that the effects of other factors should also be examined in this relationship. Researchers have revealed that if person-job fit increases job engagement will also increase. Besides, the research conducted is that the perceived supervisor support of employees is an important factor affecting their job engagement. Therefore, in this study, while examining the effect of job autonomy on job engagement, the effects of person-job fit and perceived supervisor support on this relationship were examined. Data were collected from 385 employees in two private service companies located in Turkey. The majority of the participants were women ( $54 \%$ ), $46 \%$ were between the ages of $26-31$ years, $59 \%$ were single, and $43 \%$ had graduate degrees.

SPSS 22, AMOS 22 and Process Macro (for SPSS) statistical programs were used to analyze the data. Hierarchical regression analysis was used for testing Hypothesis 1, 2 and 3, and SPSS macro program developed by Preacher and Hayes (2004) was used for testing Hypothesis 4. This program facilitates the implementation of the recommended bootstrapping methods and provides a method for testing the significance of conditional indirect effects at different values of the moderator variable. The Bootstrap method was used to test the significance of the indirect effect of work autonomy on job attachment. While using this method, the number of samples was chosen as 5000 and the confidence interval was $95 \%$.

As a result of the analyses, all of the research hypotheses were supported (Hypothesis 1, 2, 3, and 4). Research findings supported that job autonomy had a positive effect on person-job fit (Hypothesis 1), and that person-job fit had a mediating effect on the relationship between job autonomy and job engagement (Hypothesis 2). Also, the research findings revealed that the effect of person-job fit on job engagement varies according to the different levels of perceived supervisor support (Hypothesis 3). In other words, the slope (see Figure 2) of the relationship between personjob fit and job engagement was relatively strong for high perceived supervisor support, whereas the slope was relatively weak for low perceived supervisor support. The results also showed that the indirect effect of job autonomy on job engagement (through person-job fit) was strong when perceived supervisor support was high, and weak when perceived supervisor support low (Hypothesis 4).

In line with the research findings, some theoretical effects have emerged. The first theoretical effect of the findings is to clarify the relationship between job autonomy, person-job fit and job engagement. The results of the research are important in terms of contributing to the relationship between job autonomy and job engagement, and that personjob fit is also an important factor in this relationship. Perceived Supervisor Support is defined as "employee assessments of whether or not their managers care about them and value their work". These research findings contributed to the perceived supervisor support literature in terms of revealing that employees who perceive that managers provide sufficient support are more connected to their jobs. Based on the perceived supervisor support literature, perceived supervisor support was tested as a moderator in the relationship between person-job fit and job engagement. As a result 


\section{Eskişehir Osmangazi Üniversitesi ïiBF Dergisi}

of the analysis, it was seen that perceived supervisor support is an important determinant in the effect of person-job fit on job engagement.

In addition to the theoretical effects of the research results, there are also some effects for managers and organizations. Many researchers have emphasized that the person-job fit should be considered in the recruitment processes. According to Saks (2006), giving employees more autonomy and support in their work increases their job engagement. The results of this study support Saks' claim because it shows that the effect of job autonomy on job engagement through person-job fit differs according to supervisor support. Boon et al. (2011) indicated that human resources practices are an important determinant in the fitting of the employees with their jobs. For this reason, organizations need to review human resources practices and make necessary improvements to increase employee job engagement. For example, managers can increase employee job engagement by making business designs that increase job autonomy, creating a fair reward system, applying flexible working hours, increasing training opportunities and supporting career development. 